\title{
Water-Sensitivity Characteristics of Briquettes Made from High-Rank Coal
}

\author{
Yunguang Geng, Dazhen Tang, Hao Xu and Tang Shuling \\ School of Energy Resources, China University of Geosciences (Beijing), Beijing 100083, China
}

\begin{abstract}
In order to study the water sensitivity characteristics of the coalbed methane (CBM) reservoir in the southern Qinshui Basin, the scanning electron microscopy, mineral composition and the water sensitivity of main coalbed 3 cores were tested and analyzed. Because CBM reservoirs in this area are characterized by low porosity and low permeability, the common water sensitivity experiment of cores can't be used, instead, the briquettes were chose for the test to analysis the water sensitivity of CBM reservoirs. Results show that: the degree of water sensitivity in the study area varies from week to moderate. The controlling factors of water sensitivity are clay mineral content and the occurrence type of clay minerals, permeability and liquid flow rate. The water sensitivity damage rate is positively correlated with clay mineral content and liquid flow rate, and is negatively correlated with core permeability. The water sensitivity of CBM reservoir exist two damage mechanisms, including static permeability decline caused by clay mineral hydration dilatation and dynamic permeability decline caused by dispersion/migration of clay minerals.
\end{abstract}

\section{Introduction}

Coalbed methane (CBM) is a natural gas that gathers in pores and microfractures of coal seams [1]. A coalbed methane reservoir is one kind of unconventional petroleum resource where coalbed gas is developed and stored, unlike conventional natural gas reservoirs [2, 3]. Coalbeds are characterized by low mechanical strength, cleat development, strong heterogeneity and a large specific surface area compared with conventional sandstone rock. Coalbed permeability is the important factor affecting CBM well production, which is not only controlled by the factors such as coal lithotypes, pores and cleats characteristics, but also affected by different kinds of sensitivities [4-6].

Tectonic coal exists in the area with intense tectonic activity in Qinshui Basin. Based on the coal seam has the minimum strength in the coal-bearing rock series, the original structure of coal is easily destroy in the process of structural changes forming tectonic coal. According to the damage degree, tectonic coal contains fractured, granular and powdered, and characterized with disorder bedding, soft coal property, relatively high porosity and destruction or disappearance of the original structure. The structure and composition of briquette is familiar with tectonic coal, which can be applied to analysis the properties of granular tectonic coal. Huge advantage of the coal briquettes application is a possibility of obtaining a material of repeatable properties [7]. In addition the study presented in the current paper aims the coal briquetting as the important process for the outburst investigation and the process that is helpful in exploration of the dangerous coal structures which appear in the natural conditions

\section{Experimental methods}

\subsection{Materials}

Coal samples were collected from the NO.3 coal seam in Southern Qinshui Basin. Briquettes were made of artificially selected certain particle grain size of coal particles which ranges from $0.2 \sim 0.4 \mathrm{~mm}$. Briquettes are $3 \sim 3.5 \mathrm{~cm}$ long and with diameter of $2.5 \mathrm{~cm}$ (Table 1). Making process is as follows:

(1) Break the coal samples and select $0.2 \sim 0.4 \mathrm{~mm}$ coal particles

(2) Take $20 \mathrm{~g}$ particles and add $2 \mathrm{~mL}$ standard brine mixing with coal particles.

(3) Put the particles into mode and exert $17500 \mathrm{~N}$ pressure on it for 6 minutes.

Table 1. Basic parameters of the briquette samples.

\begin{tabular}{|c|c|l|c|c|}
\hline \multirow{2}{*}{ Samples } & \multicolumn{2}{|l|}{ Size /cm } & $\begin{array}{c}\text { permeability } \\
\text { /mD }\end{array}$ & $\begin{array}{c}\text { porosity } \\
\text { /\% }\end{array}$ \\
\cline { 2 - 5 } & diameter & length & 11.89 & 9.2 \\
\hline 1 & 2.5 & 3.241 & 17.32 & 11.4 \\
2 & 2.5 & 3.432 & 14.88 & 9.8 \\
3 & 2.5 & 3.501 & 14.31 & 10.1 \\
4 & 2.5 & 3.156 & 21.63 & 12.9 \\
5 & 2.5 & 3.327 & \multicolumn{2}{|c}{} \\
\hline
\end{tabular}

\subsection{Methods}

2.2.1 Mineral, microstructure and pore diameter analysis of coal samples 
The whole-rock mineral and relative clay mineral contents of the coal seam were determined by X-ray diffraction based on the Rietveld method [8, 9]. Microstructures of fresh sections were observed using an S-4800 scanning electron microscope (SEM) by secondary electron imaging [10].

\subsubsection{Formatting author names and author affiliations}

The experiment measured permeability under the flow rate of $1 \mathrm{~mL} / \mathrm{min}, 3 \mathrm{~mL} / \mathrm{min}$, and $5 \mathrm{~mL} / \mathrm{min}$ respectively under the condition of saturated $8 \% \mathrm{KCl}$ and distilled water. The permeability measurement references to Darcy formula. The differences of permeability measured under the same flow rate with the two conditions are compared. Water sensitivity damage rate is as the follow equation:

$$
D_{W}=\frac{\left|K_{i}-K_{w}\right|}{K_{i}} \times 100 \%
$$

where Dw is sensitivity damage rate; $\mathrm{Ki}$ is permeability measured under distilled water condition, $10-3 \mu \mathrm{m} 2$; Kw is permeability measured under $8 \% \mathrm{KCl}$ condition, $10-3$ $\mu \mathrm{m} 2$.

The experiment process is as follows:

(1) Put briquette sample into $8 \% \mathrm{KCl}$ for 48 hours to make it saturated.

(2) Put the saturated $8 \% \mathrm{KCl}$ sample in LDY32-300 core flow instrument and increasing confining pressure to $3.5 \mathrm{MPa}$.

(3) Conduct the displacement test using $8 \% \mathrm{KCl}$, measuring permeability under the flow rate of $1 \mathrm{~mL} / \mathrm{min}$, $3 \mathrm{~mL} / \mathrm{min}$, and $5 \mathrm{~mL} / \mathrm{min}$ respectively.
(4) Take out the sample and put it into distilled water for 48 hours to make it saturated.

(5) Repeat step (2) and step (3).

\section{Results and discussion}

\subsection{Mineral composition and occurrence manner}

The microstructure of the NO.3 coal seam in Qinshui Basin had the following characteristics: parallel grains, bedding and joints. The cleats (Fig. 1e) of the coal were easily recognized and showed good tropism with grid shaped distributions on the flat surface Micropores, including blow holes, moldic pore and deformed tissue holes, developed locally (Fig. 1a, b, d); and the pores were partially filled by clay minerals (Fig. 1d). A large number of microfractures existed (Fig. 1f), with moderate connectivity. The main fissures were $0.14-1.1 \mathrm{~cm}$ long and $270 \mathrm{~mm}$ wide. And several microfractures were also filled by clay minerals (Fig. 1f). This is the reason why coal seam characterized by low porosity and permeability. Clay minerals in micropores will hydrate once in contact with water, leading to flow path and particulate output reduction.

Vitrinite reflectance of samples was greater than 2.6. Maceral group composition contains vitrinite and collinite with no exinite existing. Non mineral composition is given priority to clay minerals and contained small amounts of carbonate (Table 2). Under the scanning electron microscopy (SEM), clay minerals such as kaolinite shaped in very thin flaky on the surface coal rock (Fig. 1c). Some epigenetic clay minerals filled in coal pores and fractures (Fig. 1d, f).

Table 2. Mineral compositions determined by X-ray diffraction.

\begin{tabular}{cccccc}
\hline Samples & Non minerals (\%) & Clay (\%) & Calcite and Dolomite (\%) & Siderite (\%) & Others (\%) \\
\hline 1 & 96.4 & 2.3 & 0.5 & 0.4 & 0.4 \\
2 & 94.3 & 5.3 & 0.2 & 0.2 & $/$ \\
3 & 91.7 & 7.1 & 0.3 & 0.9 & $/$ \\
4 & 95.1 & 4.3 & 0.2 & 0.5 & $/$ \\
5 & 88.9 & 10.3 & 0.2 & $/$ & 0.6 \\
\hline
\end{tabular}

\subsection{Water-sensitivity of coal samples}

Water-sensitivity test result showed that the permeability damage ranged from $29.92 \% \sim 54.03 \%$, the average of $43.53 \%$ (Fig. 2). The degree of water-sensitivity damage at 5 briquette samples varied from weak to moderate with no strong water-sensitivity appearance.

\subsubsection{Effect factors of water-sensitivity}

Water-sensitivity depends on the type and content of clay minerals in reservoir and underground fluid salinity. Predecessors attributed the reservoir water-sensitivity to the hydration swelling and dispersion of the clay minerals mingling under the condition of low salinity. In common clay minerals, montmorillonite has the strongest swelling capacity, followed by illite/montmorillonite mixed layer and chlorite/smectite mixed layer, because swelling ability of illite and chlorite is relatively weak, while kaolinite has no swelling ability.

The contents of clay and carbonate minerals and water-sensitivity damage rate correlation analysis result shows that the coal reservoir water sensitivity damage rate is positively correlated with clay mineral content, and is negatively related with carbonate content (Fig. 3). It suggests that the main factors causing the reservoir sensibility in this area are clay minerals. The more the pores and fractures are filled with clay mineral, the more the water-sensitivity damage rate will be.

Shown by analysis, water-sensitivity damage rate is positively correlated with flow rate (Fig. 4). Along with 
the increase of the displacement velocity water-sensitivity damage rate increases, indicating that water-sensitivity minerals are not only cause the static permeability decline, but also have a certain influence to dynamic permeability decline.
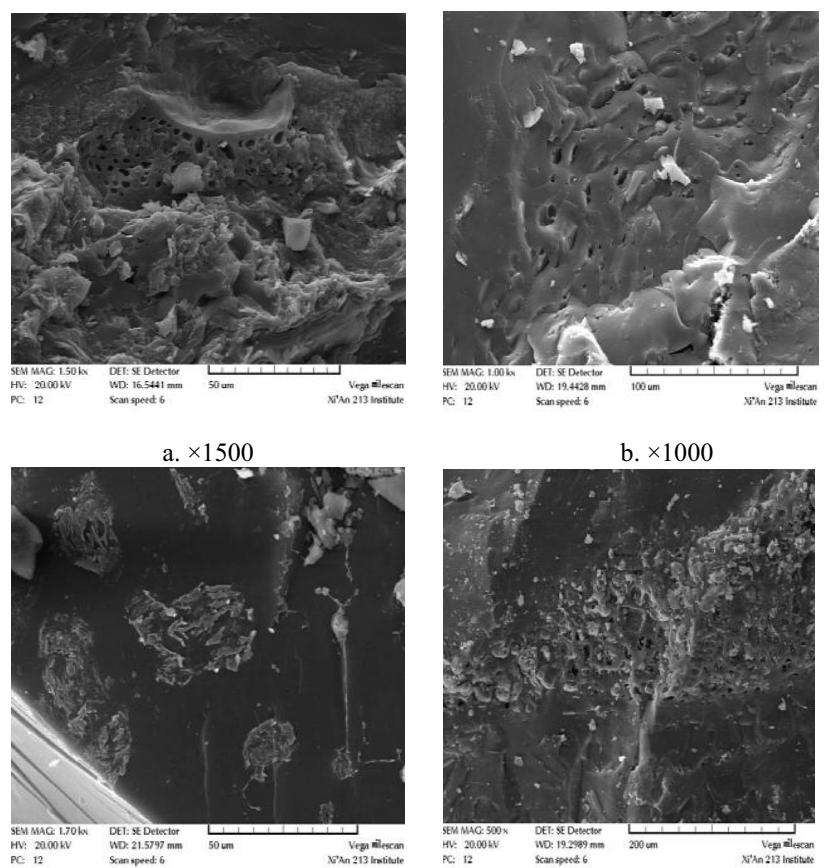

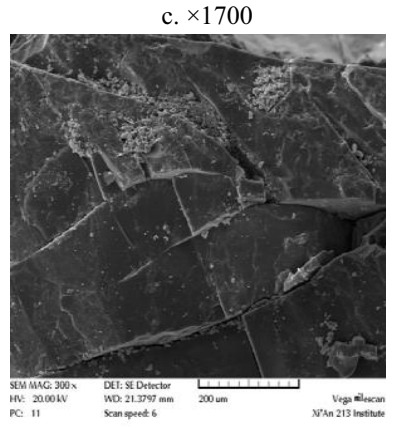

e. $\times 300$

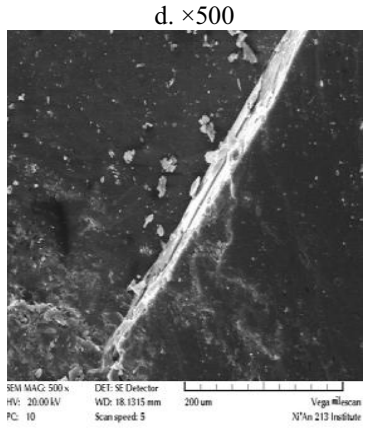

f. $\times 500$
Figure 1. Microscopic images of the coal core of the NO. 3 coal seam.

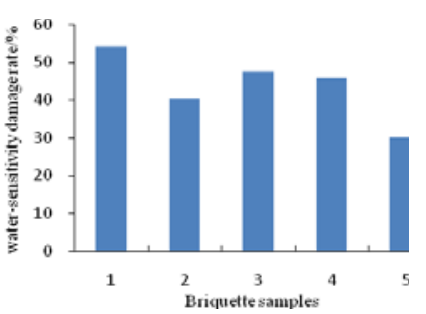

Figure 2. Water-sensitivity damage rate of briquette samples.

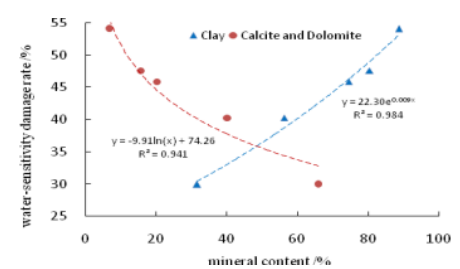

Figure 3. The relationship between water-sensitivity damage rate and mineral content under the same flow.

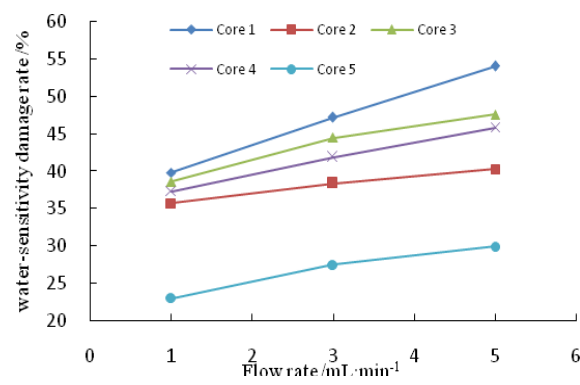

Figure 4. The relationship between water-sensitivity damage rate and flow rate.

\section{Conclusions}

(1) Maceral group composition of coal samples contains vitrinite and collinite with no exinite existing. Non mineral composition is given priority to clay minerals and contained small amounts of carbonate. Coalbed No.3 in Qinshui Basin is characterized by low porosity and low permeability; pore type is major in micropore; microfractures development, which mostly are secondary cracks with varying ages. The effective fracture length is short and with high closure degree and fillings of mineral, which cause the overall coalbed reservoir permeability is low.

(2) The coal rock from the NO.3 seam was mainly composed of carbon and a certain amount of clay minerals, making it sensitive to water. Briquettes made from high rank coal exists the following two watersensitivity mechanisms. One is under low flow rate condition, clay mineral hydration expansion blocking pore throat leads to the static permeability decline. The other is under high flow rate condition, in addition to hydration expansion mechanism, coal particles migration leads to dynamic permeability decline.

(3) Flow experiments result shows a positive correlation between cores water-sensitivity damage rate and clay mineral content and a negative correlation between the damage rate and calcite and dolomite content under the same flow rate. In addition, there is a positive correlation between the water-sensitivity damage rate and flow rate.

\section{References}

1. O. Karacan, E. Okandan, Assessment of energetic heterogeneity of coals for gas adsorption and its effect on mixture predictions for coalbed methane studies, Fuel 79, 1963-1974 (2000)

2. A. Keim, D. Luxbacher, M. Karmis, A numerical study on optimization of multilateral horizontal wellbore patterns for coalbed methane production in southern Shanxi province, China, Int. J. Coal Geol. 86, 306-317 (2011)

3. H. Xu, D. Z. Tang, S. H. Tang, J. L. Zhao, et al., A dynamic prediction model for gas-water effective permeability based on coalbed methane production data, Int. J. Coal Geol. 121, 44-52 (2014)

4. H. Kumar, D. Elsworth, J. S. Liu, et al., Optimizing enhanced coalbed methane recovery for unhindered 
production and $\mathrm{CO}_{2}$ injectivity, Int. J. Greenh. Gas. Control 11, 86-97 (2012)

5. S. Rachmat, A. Pramana, L. Febriana, Indonesia's unconventional resources, modified resource triangle, and a typical example of stimulation of coalbed methane reservoir, Mod. Appl. Sci. 6, 99-111 (2012)

6. Z. J. Pan, D. Connell, M. Camilleri, Laboratory characterisation of coal reservoir permeability for primary and enhanced coalbed methane recovery. Int. J. Coal Geol. 82, 252-261 (2010)

7. B. Dutka, M. Kudasik, Z. Pokryszka, N. Skoczylas, J. Topolnicki, M. Wierzbicki, Balance of $\mathrm{CO} 2 / \mathrm{CH} 4$ exchange sorption in a coal briquette, Fuel Process Technol. 106, 95-101 (2013)
8. C. R. Ward, J. C. Taylor, C. E. Matulis, et al., Quantification of mineral matter in the Argonne premium coals using interactive Rietveld-based Xray diffraction, Int. J. Coal Geol. 46, 67-82 (2001)

9. C. D. Ruan, C. R. Ward, Quantitative X-ray powder diffraction analysis of clay minerals in Australian coals using Rietveld methods, Appl. Clay Sci. 21, 227-240 (2002)

10. Y. D. Cai, D. M. Liu, Y. B. Yao, et al., Partial coal pyrolysis and its implication to enhance coalbed methane recovery, part I: an experimental investigation, Fuel 132, 12-19 (2014) 